\title{
Scorpionate-Type Coordination in MFU-4l Metal-Organic Frameworks: Small-Molecule Binding and Activation upon the Thermally Activated Formation of Open Metal Sites**
}

\author{
Dmytro Denysenko, Maciej Grzywa, Jelena Jelic, Karsten Reuter, and Dirk Volkmer*
}

\begin{abstract}
Postsynthetic metal and ligand exchange is a versatile approach towards functionalized MFU-4l frameworks. Upon thermal treatment of $M F U-4 l$ formates, coordinatively strongly unsaturated metal centers, such as zinc(II) hydride or copper(I) species, are generated selectively. $C u^{I}-M F U-4 l$ prepared in this way was stable under ambient conditions and showed fully reversible chemisorption of small molecules, such as $\mathrm{O}_{2}$, $\mathrm{N}_{2}$, and $\mathrm{H}_{2}$, with corresponding isosteric heats of adsorption of 53, 42, and $32 \mathrm{~kJ} \mathrm{~mol}^{-1}$, respectively, as determined by gassorption measurements and confirmed by DFT calculations. Moreover, $\mathrm{Cu}$-MFU-4l formed stable complexes with $\mathrm{C}_{2} \mathrm{H}_{4}$ and $\mathrm{CO}$. These complexes were characterized by FTIR spectroscopy. The demonstrated hydride transfer to electrophiles and strong binding of small gas molecules suggests these novel, yet robust, metal-organic frameworks with open metal sites as promising catalytic materials comprising earth-abundant metal elements.
\end{abstract}

Metal-organic frameworks with open metal sites have been proposed for many different applications, such as catalysis, ${ }^{[1]}$ gas storage and capture, ${ }^{[2]}$ separation, ${ }^{[3]}$ and sensing. ${ }^{[4]}$ However, most known MOFs with free metal centers are only able to bind typical Lewis bases, such as $\mathrm{CO}_{2}$ or $\mathrm{H}_{2} \mathrm{O}$, whereas the activation of unreactive small molecules, such as $\mathrm{O}_{2}, \mathrm{~N}_{2}$, and $\mathrm{H}_{2}$, still remains a challenge.

Molecular dioxygen, ${ }^{[5]}$ dinitrogen,${ }^{[5]}$ and dihydrogen ${ }^{[6]}$ complexes have attracted significant attention in coordination chemistry. Only very few stable MOFs with open metal centers have been described that are able to bind these molecules. A structural analogue of CuBTC, $\mathrm{Cr}_{2}{ }_{2}{ }_{2}(\mathrm{BTC})_{3}$, containing dinuclear $\mathrm{Cr}^{\mathrm{II}}$ paddle-wheel units, was shown to bind oxygen at room temperature. ${ }^{[7]}$ However, after the first adsorption step, only approximately $82 \%$ of the total amount of oxygen could be desorbed, thus indicating that $18 \%$ of the $\mathrm{O}_{2}$ binds irreversibly. CPO-27 (also termed MOF-74) is

[*] D. Denysenko, Dr. M. Grzywa, Prof. Dr. D. Volkmer

Universität Augsburg, Institut für Physik

Lehrstuhl für Festkörperchemie

Universitätsstrasse 1, 86159 Augsburg (Germany)

E-mail: dirk.volkmer@physik.uni-augsburg.de

Dr. J. Jelic, Prof. Dr. K. Reuter

Technische Universität München

Chair of Theoretical Chemistry and Catalysis Research Center

Lichtenbergstrasse 4, 85747 Garching (Germany)

[**] We gratefully acknowledge funding by the priority program 1362 "Porous Metal-Organic Frameworks (MOFs)" of the Deutsche Forschungsgemeinschaft (DFG). another well-established MOF family with interesting chemisorption properties. CPO-27-Fe, for example, showed reversible chemisorption of $\mathrm{O}_{2}$ and $\mathrm{N}_{2}$ with initial heats of adsorption of 41 and $35 \mathrm{~kJ} \mathrm{~mol}^{-1}$, respectively. However, $\mathrm{O}_{2}$ chemisorption was reversible at $-62^{\circ} \mathrm{C}$, whereas at room temperature the irreversible formation of a dimeric iron(III) peroxide was observed. ${ }^{[8]} \mathrm{A}$ weak chemisorption of hydrogen with well-defined 1:1 stoichiometry (metal sites $/ \mathbf{H}_{2}$ ) was reported for $\mathrm{CPO}-27-\mathrm{Ni}$, with an initial heat of adsorption of $13.5 \mathrm{~kJ} \mathrm{~mol}^{-1}$, which ranks among the highest values reported for a MOF material. ${ }^{[9]}$ In contrast, compound 5, presented herein, shows fully reversible binding of $\mathrm{O}_{2}, \mathrm{~N}_{2}$, and $\mathrm{H}_{2}$ molecules under ambient conditions. To the best of our knowledge, no copper(I)-containing metal-organic framework has previously been shown to possess similar chemisorption properties, although IR investigations on monomeric $\mathrm{CuCl}$ embedded in an $\mathrm{Ar}$ matrix gave first experimental proof of the formation of a $\mathrm{Cu}^{\mathrm{I}}-\mathrm{H}_{2}$ complex, in which $\mathrm{H}_{2}$ binds in a side-on coordination mode. ${ }^{[10]}$ The chemisorption of $\mathrm{N}_{2}{ }^{[11]}$ and $\mathrm{H}_{2}{ }^{[12]}$ on copper-exchanged zeolites has also been described previously. For these microporous compounds, $\mathrm{Cu}^{\mathrm{I}}-\mathrm{N}_{2}$ and $\mathrm{Cu}-\mathrm{H}_{2}$ adducts were characterized by spectroscopic methods (mainly IR spectroscopy). However, presumably as a result of the relatively low $\mathrm{Cu}^{\mathrm{I}}$ content, no accurate values of $\mathrm{N}_{2}$ or $\mathrm{H}_{2}$ binding energies were reported.

We herein describe a new approach towards such highly active metal centers in a metal-organic framework based on MFU-4l, constructed from bistriazolate BTDD $^{2-}$ ligands and $\left\{\mathrm{Zn}_{5} \mathrm{Cl}_{4}\right\}^{6+}$ building units (Figure 1). ${ }^{[13]}$ Coordination frameworks derived from the MFU-4 family show exceptional robustness against thermal and hydrolytic decomposition ${ }^{[14]}$ and are therefore attractive for technical applications, such as
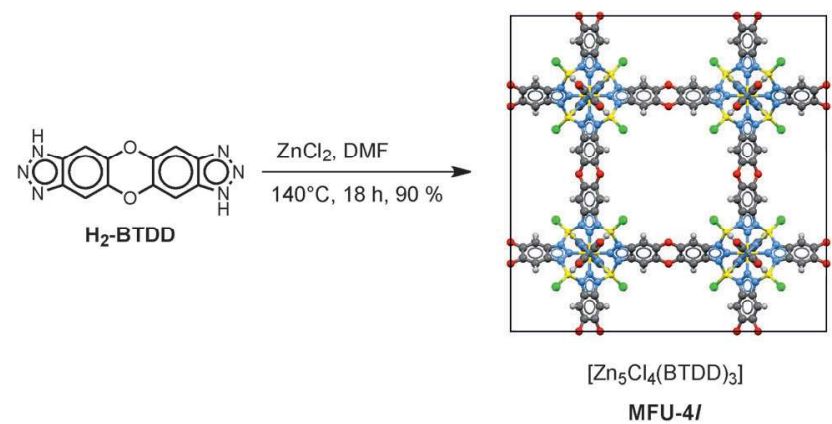

Figure 1. Solvothermal synthesis of MFU-4l. Atom colors: $\mathrm{Zn}$ (octahedral) pink, $\mathrm{Zn}$ (tetrahedral) yellow, $\mathrm{Cl}$ green, $\mathrm{O}$ red, $\mathrm{N}$ blue, $\mathrm{C}$ gray, $\mathrm{H}$ white. The black square outlines the cubic unit cell of MFU-4l (space group: $F m \overline{3} m, a=31.057 \AA$; see Ref.[13]). 
gas separation ${ }^{[15]}$ and catalysis. ${ }^{[16]}$ Their fundamental building units, so-called Kuratowski units, ${ }^{[17]}$ feature coordination sites reminiscent of scorpionate-type complexes. ${ }^{[18]}$ In contrast to the latter, however, the coordination sites in MFU-4 frameworks do not have to be protected from unfavorable side reactions by bulky substituents $\mathrm{R}$ (Figure $2 \mathrm{a}$ ). As a result, frameworks can be generated that contain free metal centers
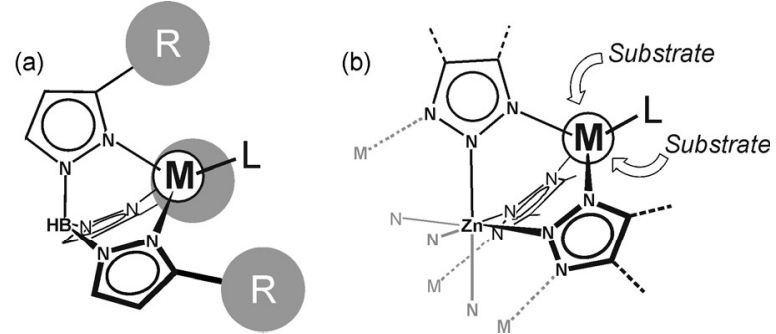

Figure 2. a) Scorpionate complex. b) Part of the fundamental building unit (Kuratowski unit) of MFU-4-type frameworks comprising coordinatively unsaturated, substrate-accessible coordination sites $(M=$ (transition) metal, $L=$ ligand, $R=$ bulky substituent, for example, $t B u$ ).

with (almost) unconstrained substrate accessibility (Figure $2 \mathrm{~b}$ ). With the aim of constructing catalytically active frameworks, suitable MFU- $4 l$ derivatives can be used as starting materials, within which the required coordinatively highly unsaturated metal centers can be formed. The first example, as shown below, establishes the formation of a highly reactive zinc(II) hydride species $\mathbf{2}$, generated from MFU-4l-formate (1), which was readily obtained from MFU$4 l$ through chloride-formate ligand exchange (Figure 3, path a). Alternatively, postsynthetic metal metathesis, that is, the replacement of $\mathrm{Zn}^{\mathrm{II}}-\mathrm{Cl}$ units with $\mathrm{Cu}^{\mathrm{I}}$ ions (Figure 3, path $\mathrm{b}$ ), led to threefold-coordinated unsaturated $\mathrm{Cu}^{\mathrm{I}}$ sites that showed reversible and remarkably strong chemisorption of small molecules (i.e. $\mathrm{H}_{2}, \mathrm{O}_{2}, \mathrm{~N}_{2}$, and $\mathrm{C}_{2} \mathrm{H}_{4}$ ) under ambient conditions.

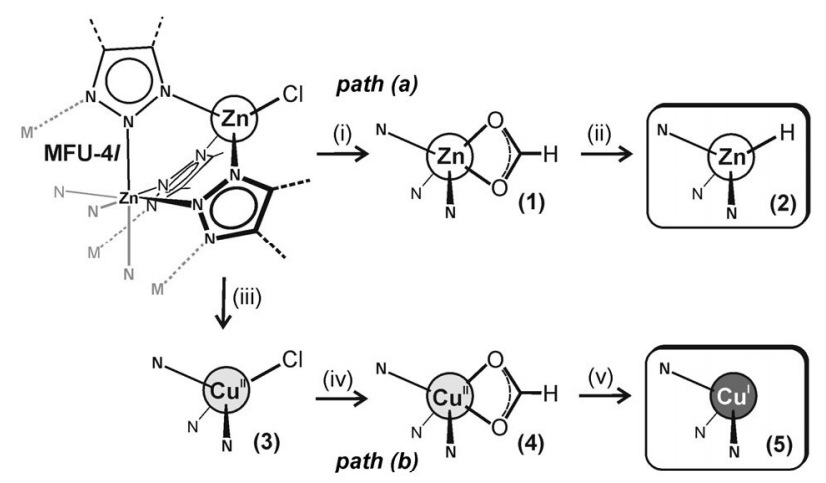

Figure 3. Reaction paths leading to MFU-4/ derivatives $\mathbf{2}$ and $\mathbf{5}$ with active metal sites. Reaction conditions: i) $\mathrm{HCOOLi} / \mathrm{MeOH}$, room temperature; ii) $300^{\circ} \mathrm{C}, 30 \mathrm{~min}$, under vacuum; iii) $\mathrm{CuCl}_{2}, \mathrm{DMA}, 60^{\circ} \mathrm{C}$; iv) $\mathrm{HCOOLi} / \mathrm{MeOH}$, room temperature; v) $180^{\circ} \mathrm{C}, 1 \mathrm{~h}$, under vacuum. $\mathrm{DMA}=\mathrm{N}, \mathrm{N}$-dimethylacetamide.
Thermally activated decomposition of bulk metal formates has been reported previously. The decomposition of zinc formate, for example, leads to $\mathrm{ZnO}$, whereas copper(II) formate yields the reduced products $\mathrm{Cu}_{2} \mathrm{O}$ and $\mathrm{Cu}^{[19]}$ Our studies show that the thermally induced decomposition of coordinated formate ligands is a versatile approach for generating reactive metal sites in MFU-4l-type porous materials. Thus, the decomposition of $\mathbf{1}$ under flowing nitrogen gas took place in the temperature range of $190-280^{\circ} \mathrm{C}$, as shown by the curve derived from thermogravimetric analysis (TGA; see Figure S1 in the Supporting Information), whereby the crystalline order of the framework remained unchanged (see Figure S27). FTIR spectra showed clearly the formation of $\mathrm{Zn}-\mathrm{H}$ species (i.e. 2; Figure 3). Thus, a characteristic $\mathrm{Zn}$-formate stretching vibration, which appeared as a shoulder in the FTIR spectrum at $1610 \mathrm{~cm}^{-1}$, disappeared completely when compound $\mathbf{1}$ was heated at $300^{\circ} \mathrm{C}$ (Figure 4).

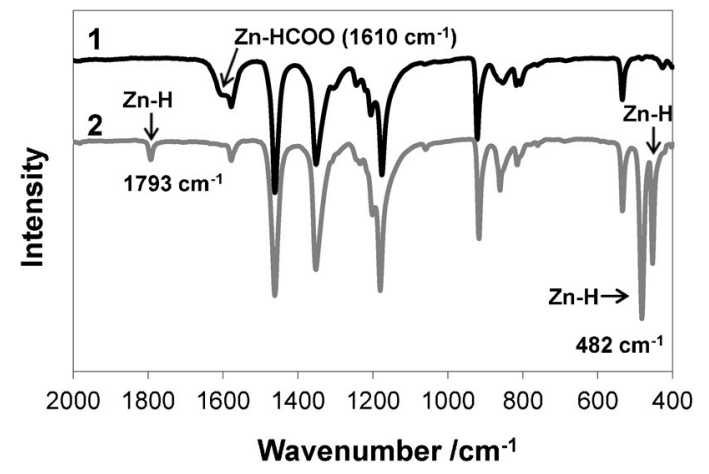

Figure 4. FTIR spectra of 1 and 2.

Three new bands appeared upon heat treatment: at 1793, 482, and $453 \mathrm{~cm}^{-1}$. On the basis of DFT calculations (using the PBE functional) ${ }^{[20]}$ corrected for dispersive interactions, ${ }^{[21]}$ we assign these bands to a $\mathrm{Zn}-\mathrm{H}$ stretch mode and two $\mathrm{Zn}-\mathrm{H}$ bending modes, respectively (see Figures S29 and S30).

Molecular hydride complexes of zinc scorpionates, prepared in a different way (either starting from $\mathrm{ZnH}_{2}$ or by treatment of a $\mathrm{Zn}-\mathrm{F}$ precursor with $\mathrm{Et}_{3} \mathrm{SiH}$ ), have been reported previously. These zinc hydride scorpionates were shown to react with various electrophiles, such as $\mathrm{CO}_{2}, \mathrm{CS}_{2}$, RNCS, RI, and $\mathrm{CH}_{3} \mathrm{COCl}^{\left[{ }^{[2]}\right]}$ To demonstrate a comparable reactivity of the MFU- $4 l$ hydride derivative $\mathbf{2}$, we added $\mathrm{PhCOCl}$ to a suspension of $\mathbf{2}$ in benzene at room temperature and obtained $\mathrm{PhCHO}$ as the main product, as determined by GC/MS analysis (see Figure S23). This test case indicates the potential of the hydride-containing MFU-4l-type framework 2 as a hydride-transfer and reducing agent.

We previously showed that all four peripheral $\mathrm{Zn}^{\mathrm{II}}$ ions of each Kuratowski unit in MFU- $4 l$ could be substituted by $\mathrm{CO}^{\mathrm{II}}$ upon heating with $\mathrm{CoCl}_{2}$ in $\mathrm{DMF}^{[16]}$ An equivalent approach with $\mathrm{CuCl}_{2}$ led to $\mathrm{Cu}^{\mathrm{II}}-\mathrm{MFU}-4 l(3)$, in which, however, on average only two out of four tetrahedrally coordinated $\mathrm{Zn}$ centers per Kuratowski unit are replaced with $\mathrm{Cu}^{\mathrm{II}}$ ions. $\mathrm{Cu}^{\mathrm{II}}$ MFU-4l-formate (4) could then be readily prepared by a subsequent ligand-exchange reaction, in analogy to the 
synthesis of 1 (Figure 3). The TGA curve (see Figure S1) shows that $\mathbf{4}$ decomposes in two steps: The first weight loss at $120-180^{\circ} \mathrm{C}$ corresponds to the decomposition of $\mathrm{Cu}^{\mathrm{II}}$-formate units, and the second weight loss at $190-280^{\circ} \mathrm{C}$ corresponds to the transformation of $\mathrm{Zn}$-formate units. Sorption and spectroscopic studies showed that thermal activation of $\mathbf{4}$ led finally to a MFU-4l-type framework with free $\mathrm{Cu}^{\mathrm{I}}$ centers, termed $\mathrm{Cu}^{\mathrm{I}}-\mathrm{MFU}-4 l$ (5; Figure 3 ). As proven by gas-sorption measurements, $\mathbf{5}$ formed very stable complexes with $\mathrm{CO}$ and $\mathrm{C}_{2} \mathrm{H}_{4}$.

The quantity of bound species (ca. $38 \mathrm{~cm}^{3} \mathrm{~g}^{-1}$; see Figures S13 and S14) was nearly identical for both gases and very close to the calculated value $\left(37.8 \mathrm{~cm}^{3} \mathrm{~g}^{-1}\right)$ based on the analytically determined $\mathrm{Cu}$ content, thus suggesting the formation of stable $1: 1 \mathrm{Cu}^{\mathrm{I}}-\mathrm{CO}$ and $\mathrm{Cu}^{\mathrm{I}}-\mathrm{C}_{2} \mathrm{H}_{4}$ coordination units. The corresponding stretch modes of coordinatively bound $\mathrm{CO}$ and $\mathrm{C}_{2} \mathrm{H}_{4}$ molecules were observed in the FTIR spectra at 2081 and $1541 \mathrm{~cm}^{-1}$, respectively (Figure 6b), in good agreement with the DFT-calculated values (2056 and $1517 \mathrm{~cm}^{-1}$, respectively). Both vibrational frequencies are shifted to lower wavenumbers, as compared to those of the free gas molecules $\left(2143 \mathrm{~cm}^{-1}\right.$ for CO and $1623 \mathrm{~cm}^{-1}$ for $\left.\mathrm{C}_{2} \mathrm{H}_{4}\right) \cdot{ }^{[23]}$ One of the most interesting properties of $\mathbf{5}$ is the unprecedented strong and reversible chemisorption of $\mathrm{H}_{2}$. The amount of chemisorbed $\mathrm{H}_{2}\left(38 \mathrm{~cm}^{3} \mathrm{~g}^{-1}\right.$; Figure $5 \mathrm{a}$; see also Figure S13) was the same as for $\mathrm{CO}$ and $\mathrm{C}_{2} \mathrm{H}_{4}$, which indicates a $1: 1$ stoichiometry of $\mathrm{Cu}^{\mathrm{I}}-\mathrm{H}_{2}$ coordination units. The adsorption/desorption isotherm measured at $273 \mathrm{~K}$ demonstrates full reversibility of hydrogen binding. Under equilibrium conditions ( 1 bar $\mathrm{H}_{2}$ pressure), approximately $80 \%$ of all $\mathrm{Cu}^{\mathrm{I}}$ centers formed a 1:1 hydrogen complex at this temperature (Figure 5b). The isosteric heat of hydrogen

(a)

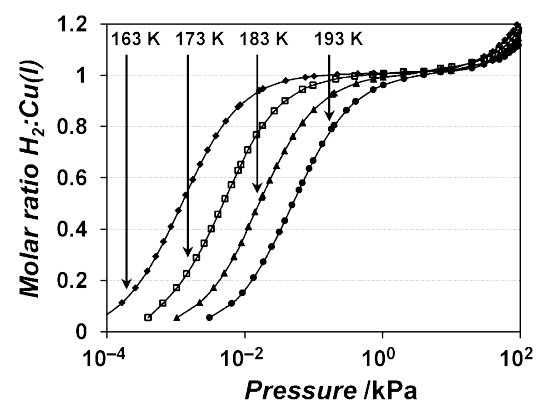

(b)

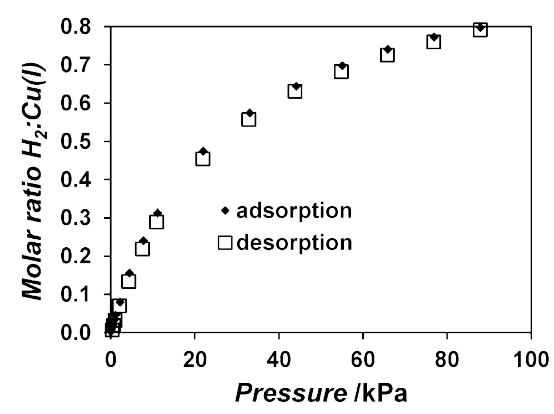

Figure 5. a) Hydrogen-adsorption isotherms on 5 at 163-193 K. b) Hydrogen-adsorption/desorption isotherm on 5 at $273 \mathrm{~K}$. adsorption, as calculated by using the Clausius-Clapeyron equation, is $32 \mathrm{~kJ} \mathrm{~mol}^{-1}$, again in very good agreement with the DFT-calculated value of $25 \mathrm{~kJ} \mathrm{~mol}^{-1}$ (Table 1). The $\mathrm{Cu}-\mathrm{H}_{2}$ bonding energy in $\mathrm{Cu}^{\mathrm{I}}-\mathrm{MFU}-4 l(5)$ is thus significantly higher

Table 1: Experimental and DFT-calculated isosteric heats of adsorption in $\mathrm{kJ} \mathrm{mol}^{-1}$ in $\mathrm{Cu}^{\mathrm{l}}-\mathrm{MFU}-4 \mathrm{l}(\mathbf{5})$

\begin{tabular}{llllll}
\hline & $\mathrm{H}_{2}$ & $\mathrm{~N}_{2}$ & $\mathrm{O}_{2}$ & $\mathrm{C}_{2} \mathrm{H}_{4}$ & $\mathrm{CH}_{4}$ \\
\hline experiment & $32.3 \pm 0.4$ & $41.6 \pm 0.6$ & $52.6 \pm 0.6$ & $88 \pm 4$ & $14.9 \pm 0.4$ \\
DFT-B3LYP & 25 & 44 & 46 & 84 & 15 \\
\hline
\end{tabular}

than typical values for $\mathrm{H}_{2}$ physisorption $\left(5-10 \mathrm{~kJ} \mathrm{~mol}^{-1}\right),{ }^{[24]}$ but also significantly lower than in ionic metal hydrides or Kubas-type metal dihydrogen complexes, which normally require high desorption temperatures of $150-400^{\circ} \mathrm{C} \cdot{ }^{[25]}$ For example, an activation energy for hydrogen desorption of $156 \mathrm{~kJ} \mathrm{~mol}^{-1}$ has been measured for $\mathrm{Mg}_{2} \mathrm{NiH}_{4} \cdot{ }^{\left[{ }^{[6]}\right.}$ Intermetallic compounds, such as $\mathrm{LaNi}_{5}$, show significantly lower desorption temperatures (as low as room temperature); however, they feature only low hydrogen-storage capacities. ${ }^{[25]}$

In fact, the hydrogen binding at the $\mathrm{Cu}^{\mathrm{I}}$ centers matches well a suggested optimal binding energy of approximately $25 \mathrm{~kJ} \mathrm{~mol}^{-1}$ for hydrogen storage, thus enabling the accumulation and release of hydrogen at close to ambient temperature. ${ }^{[2]}$ Although the amount of chemisorbed hydrogen in $\mathbf{5}$ is not high $(0.34 \mathrm{wt} \%)$, owing to the low volumetric density of $\mathrm{Cu}^{\mathrm{I}}$ centers, this degree of chemisorption is possible at close to ambient temperature and pressure, thus indicating the great potential of copper(I)-containing materials with a higher density of active metal sites for hydrogen storage. Higher storage capacities have only been observed either at low temperature or at high pressure. ${ }^{[27]}$ For example, CPO-27-Ni showed less than $0.3 \mathrm{wt} \% \mathrm{H}_{2}$ uptake at $298 \mathrm{~K}$ and 65 bar. $^{[28]}$ Compound 5 also showed reversible chemisorption of $\mathrm{N}_{2}$ and $\mathrm{O}_{2}$ with the same 1:1 stoichiometry (see Figure S13) and isosteric heats of adsorption of 42 and $53 \mathrm{~kJ} \mathrm{~mol}^{-1}$, respectively (Figure $6 \mathrm{a}$ ). In contrast, methane showed only physisorption, as indicated by the low value of $15 \mathrm{~kJ} \mathrm{~mol}^{-1}$ determined for the isosteric heat of adsorption (Figure $6 \mathrm{a}$; see also Figure S14). This value was also confirmed by DFT calculations (Table 1), which showed only dispersive interactions between $\mathrm{Cu}^{\mathrm{I}}$ centers and $\mathrm{CH}_{4}$ (see Figure S31). The fact that methane does not bind to $\mathrm{Cu}^{\mathrm{I}}$ centers suggests 5 as a potential candidate for $\mathrm{CH}_{4} / \mathrm{N}_{2}$ separation with highly selective $\mathrm{N}_{2}$ uptake. In the case of normal physisorption, most frequently observed in porous materials, $\mathrm{CH}_{4}$ is adsorbed preferentially over $\mathrm{N}_{2} \cdot{ }^{[29]}$ The exceptionally high difference of $73 \mathrm{~kJ} \mathrm{~mol}^{-1}$ between the heats of adsorption of $\mathrm{C}_{2} \mathrm{H}_{4}$ and $\mathrm{CH}_{4}$ indicates that 5 is a very promising material for alkene/alkane separation or alkene capture. The isosteric heat of ethylene adsorption on CPO-27-Fe, for comparison, is about $45 \mathrm{~kJ} \mathrm{~mol}^{-1}$ and is the highest within the series of CPO-27 frameworks containing different metal ions $\left(\mathrm{Mg}^{2+}, \mathrm{Mn}^{2+}\right.$, $\mathrm{Fe}^{2+}, \mathrm{Co}^{2+}, \mathrm{Ni}^{2+}$, and $\mathrm{Zn}^{2+}$ ), whereas the heat of $\mathrm{CH}_{4}$ adsorption on CPO-27-Fe is $20 \mathrm{~kJ} \mathrm{~mol}^{-1} \cdot{ }^{[30]}$ As summarized in Table 1, all isosteric heats of adsorption were very well reproduced in DFT calculations, thus confirming the picture 
(a)

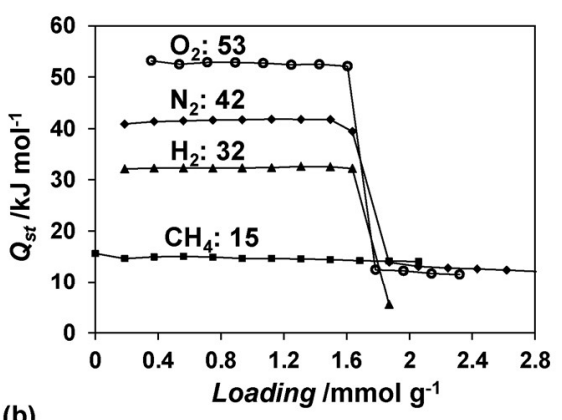

(b)

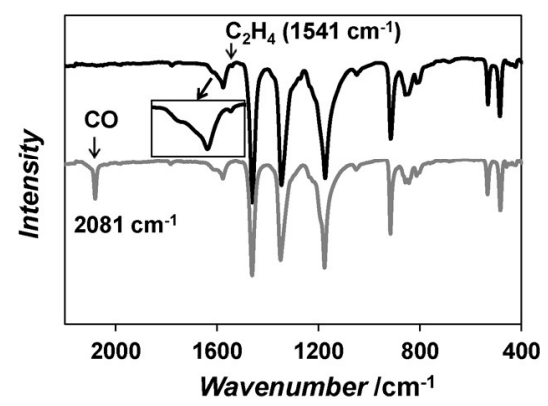

Figure 6. a) Dependence of isosteric heat of adsorption on loading for different gases on 5. b) FTIR spectra of $\mathrm{CO}$ and $\mathrm{C}_{2} \mathrm{H}_{4}$ complexes of $\mathbf{5}$.

of highly reactive and accessible $\mathrm{Cu}^{\mathrm{I}}$ centers in $\mathrm{Cu}^{\mathrm{I}}-\mathrm{MFU}-4 l$ (5).

We further note that $\mathbf{5}$ is air-stable (meaning that it is not oxidized irreversibly or destroyed in air like many copper(I)containing compounds) and changes its color reversibly from slightly yellow (in a vacuum) to dark-gray (in air), which indicates the reversible binding of $\mathrm{O}_{2}$ molecules at the $\mathrm{Cu}^{\mathrm{I}}$ centers. Quantitative information about this process was gleaned by UV/Vis spectroscopy (see Figure S3). The binding of nitrogen was followed by diffuse reflectance infrared Fourier transform (DRIFT) spectroscopy. The experimental frequency for the IR-active $\mathrm{N}-\mathrm{N}$ bond stretch $\left(2242 \mathrm{~cm}^{-1}\right.$; see Figure S10) is typical for $\mathrm{Cu}^{\mathrm{I}}-\mathrm{N}_{2}$ adducts, as previously described, ${ }^{[1]}$ and close to the DFT-calculated value $\left(2215 \mathrm{~cm}^{-1}\right)$. As observed for $\mathrm{CO}$ and $\mathrm{C}_{2} \mathrm{H}_{4}$, the $\mathrm{N}-\mathrm{N}$ vibrational frequency was shifted to lower wavenumbers as compared to that of the free $\mathrm{N}_{2}$ molecule $\left(2331 \mathrm{~cm}^{-1}\right) \cdot{ }^{[23]}$

The DFT-calculated geometries of the formed $\mathrm{Cu}^{\mathrm{I}}-\mathrm{H}_{2}$, $\mathrm{Cu}^{\mathrm{I}}-\mathrm{N}_{2}, \mathrm{Cu}^{\mathrm{I}}-\mathrm{O}_{2}$, and $\mathrm{Cu}^{\mathrm{I}}-\mathrm{C}_{2} \mathrm{H}_{4}$ complexes in the Kuratowski unit are presented in Figure 7. $\mathrm{H}_{2}$ binds in an $\eta^{2}$ (side-on) mode with a $\mathrm{H}-\mathrm{H}$ bond distance of $0.83 \AA$ and a $\mathrm{Cu}-\mathrm{H}$ bond distance of $1.66 \AA$ (Figure $7 \mathrm{a}$ ). $\mathrm{N}_{2}$ binds in an $\eta^{1}$ (end-on) mode with a $\mathrm{N}-\mathrm{N}$ bond distance of $1.12 \AA$ and a $\mathrm{Cu}-\mathrm{N}$ bond distance of $1.83 \AA$; the $\mathrm{Cu}-\mathrm{N}-\mathrm{N}$ angle is $180^{\circ}$ (Figure 7b). $\mathrm{O}_{2}$ also binds in an $\eta^{1}$ (end-on) mode with an $\mathrm{O}-\mathrm{O}$ bond distance of $1.29 \AA$, a $\mathrm{Cu}-\mathrm{O}$ bond distance of $1.92 \AA$, and a $\mathrm{Cu}-\mathrm{O}-\mathrm{O}$ angle of $105.7^{\circ}$ (Figure $7 \mathrm{c}$ ). $\mathrm{C}_{2} \mathrm{H}_{4}$ forms an $\eta^{2}$ (side-on) complex with a $\mathrm{C}-\mathrm{C}$ bond distance of $1.39 \AA$ and a $\mathrm{Cu}-\mathrm{C}$ bond distance of $2.03 \AA$ (Figure $7 \mathrm{~d}$ ). All atomic distances within the bound species are longer than in the free molecules $\left(0.74,1.10,1.21\right.$, and $1.34 \AA$ for $\mathrm{H}_{2}, \mathrm{~N}_{2}, \mathrm{O}_{2}$, and $\mathrm{C}_{2} \mathrm{H}_{4}$, respectively), ${ }^{[23]}$ in agreement with the experimentally observed red shifts of the stretch frequencies for $\mathrm{N}_{2}$ and $\mathrm{C}_{2} \mathrm{H}_{4}$. a)

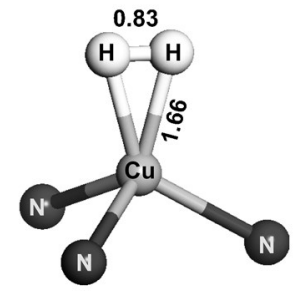

c)

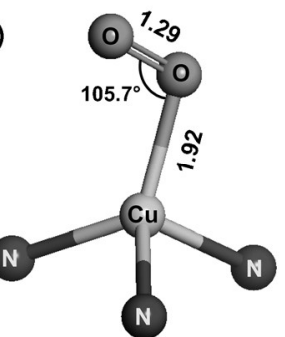

b)

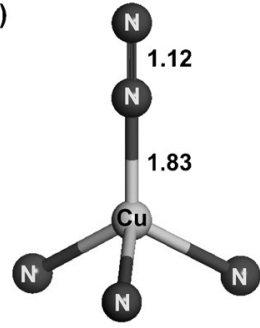

d)

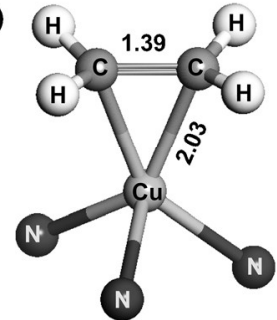

Figure 7. Binding geometries for a) $\mathrm{H}_{2}$, b) $\mathrm{N}_{2}$, c) $\mathrm{O}_{2}$, and d) $\mathrm{C}_{2} \mathrm{H}_{4}$ at the $\mathrm{Cu}$ ' sites within the Kuratowski unit of MFU-4l, as determined by DFT calculations (interatomic distances in $\AA$ ).

In summary, we have provided sound experimental and theoretical evidence for the synthesis, structure, and reactivity of robust metal-organic frameworks featuring open metal sites. The reactivity of these frameworks, which are derived from the MFU- $4 l$ structural family, towards small molecules was demonstrated by hydride transfer to electrophiles and by strong binding of small gas molecules. Since both processes are fundamental steps of catalytic transformation processes, further investigations in this direction should be highly rewarding. Selective chemisorption properties of $\mathrm{Cu}^{\mathrm{I}}$ centers are of great interest for the storage, separation, and sensing of small gas molecules.

\section{Experimental Section}

Detailed synthetic procedures and characterization, TGA, XRPD, and GC/MS data, FTIR and UV/Vis/NIR spectra, gas-sorption isotherms, crystallographic data, and details of the DFT calculations are provided in the Supporting Information. CCDC 971404 (1), 971402 (3), and 971403 (4) contain the supplementary crystallographic data for this paper. These data can be obtained free of charge from The Cambridge Crystallographic Data Centre via www.ccdc. cam.ac.uk/data_request/cif.

[1] P. Valvekens, F. Vermoortele, D. De Vos, Catal. Sci. Technol. 2013, 3, 1435-1445.

[2] a) B. Chen, N. W. Ockwig, A. R. Millward, D. S. Contreras, O. M. Yaghi, Angew. Chem. 2005, 117, 4823-4827; Angew. Chem. Int. Ed. 2005, 44, 4745-4749; b) J. Park, H. Kim, S. S. Han, Y. Yung, J. Phys. Chem. Lett. 2012, 3, 826-829. 
[3] a) P. D. C. Dietzel, V. Besikiotis, R. Blom, J. Mater. Chem. 2009, 19, 7362-7370; b) H. Oh, I. Savchenko, A. Mavrandonakis, T. Heine, M. Hirscher, ACS Nano 2014, 8, 761-770.

[4] B. Chen, Y. Yang, F. Zapata, G. Lin, G. Qian, E. B. Lobkovski, Adv. Mater. 2007, 19, 1693-1696.

[5] P. L. Holland, Dalton Trans. 2010, 39, 5415-5425.

[6] G. J. Kubas, Metal Dihydrogen and $\sigma$-Bond Complexes, Kluwer Academic Publishers, New York, 2001

[7] L. J. Murray, M. Dinca, J. Yano, S. Chavan, S. Bordiga, C. M Brown, J. R. Long, J. Am. Chem. Soc. 2010, 132, 7856-7857.

[8] E. D. Bloch, L. J. Murray, W. L. Queen, S. Chavan, S. N. Maximoff, J. P. Bigi, R. Krishna, V. K. Peterson, F. Grandjean, G. J. Long, B. Smit, S. Bordiga, C. M. Brown, J. R. Long, J. Am. Chem. Soc. 2011, 133, 14814-14822.

[9] P. D. C. Dietzel, P. A. Georgiev, J. Eckert, R. Blom, T. Strässle, T. Unruh, Chem. Commun. 2010, 46, 4962-4964.

[10] H. S. Plitt, M. R. Bär, R. Ahlrichs, H. Schnöckel, Angew. Chem. 1991, 103, 848-850; Angew. Chem. Int. Ed. Engl. 1991, 30, 832 834.

[11] a) A. I. Serykh, M. D. Amiridis, Microporous Mesoporous Mater. 2006, 94, 320-324; b) Y. Kuroda, Y. Yoshikawa, S.-i. Konno, H. Hamano, H. Maeda, R. Kumashiro, M. Nagao, J. Phys. Chem. 1995, 99, 10621-10628; c) Y. Kuroda, Y. Yoshikawa, S. Emura, R. Kumashiro, M. Nagao, J. Phys. Chem. B 1999, 103, 2155-2164; d) Y. Kuroda, S.-i. Konno, K. Morimoto Y. Yoshikawa, J. Chem. Soc. Chem. Commun. 1993, 18-20; e) G. Spoto, S. Bordiga, G. Ricchiardi, D. Scarano, A. Zecchina, F. Geobaldo, J. Chem. Soc. Faraday Trans. 1995, 91, 3285-3290.

[12] a) A. I. Serykh, V. B. Kazansky, Phys. Chem. Chem. Phys. 2004, 6, 5250-5255; b) X. Solans-Monfort, V. Branchadell, M. Sodupe, C. M. Zicovich-Wilson, E. Gribov, G. Spoto, C. Busco, P. Ugliengo, J. Phys. Chem. B 2004, 108, 8278-8286; c) G. Spoto, E. Gribov, S. Bordiga, C. Lamberti, G. Ricchiardi, D. Scarano, A Zecchina, Chem. Commun. 2004, 2768-2769.

[13] D. Denysenko, M. Grzywa, M. Tonigold, B. Streppel, I. Krkljus, M. Hirscher, E. Mugnaioli, U. Kolb, J. Hanss, D. Volkmer, Chem. Eur. J. 2011, 17, 1837-1848.

[14] a) S. Biswas, M. Grzywa, H. P. Nayek, S. Dehnen, I. Senkovska, S. Kaskel, D. Volkmer, Dalton Trans. 2009, 6487-6495; b) P. Schmieder, D. Denysenko, M. Grzywa, B. Baumgärtner, I. Senkovska, S. Kaskel, G. Sastre, L. van Wüllen, D. Volkmer, Dalton Trans. 2013, 42, 10786-10797.

[15] a) J. Teufel, H. Oh, M. Hirscher, M. Wahiduzzaman, L. Zhechkov, A. Kuc, T. Heine, D. Denysenko, D. Volkmer, Adv.
Mater. 2013, 25, 635-639; b) A. Soleimani Dorcheh, D. Denysenko, D. Volkmer, W. Donner, M. Hirscher, Microporous Mesoporous Mater. 2012, 162, 64-68.

[16] D. Denysenko, T. Werner, M. Grzywa, A. Puls, V. Hagen, G. Eickerling, J. Jelic, K. Reuter, D. Volkmer, Chem. Commun. 2012, 48, 1236-1238.

[17] a) S. Biswas, M. Tonigold, D. Volkmer, Z. Anorg. Allg. Chem. 2008, 634, 2532-2538; b) S. Biswas, M. Tonigold, M. Speldrich, P. Kögerler, M. Weil, D. Volkmer, Inorg. Chem. 2010, 49, 74247434.

[18] S. Trofimenko, Chem. Rev. 1993, 93, 943-980.

[19] a) K. A. Buzdov, B. D. Antonov, Russ. J. Inorg. Chem. 2012, 57, 1599-1605; b) A. K. Galwey, D. M. Jamieson, M. E. Brown, J. Phys. Chem. 1974, 78, 2664-2670.

[20] a) V. Blum, R. Gehrke, F. Hanke, P. Havu, V. Havu, X. Ren, K. Reuter, M. Scheffler, Comput. Phys. Commun. 2009, 180, $2175-$ 2196; b) X. Ren, P. Rinke, V. Blum, J. Wieferink, A. Tkatchenko, A. Sanfilippo, K. Reuter, M. Scheffler, New J. Phys. 2012, 14, 053020 ; c) J. P. Perdew, K. Burke, M. Ernzerhof, Phys. Rev. Lett. 1996, 77, 3865-3868.

[21] A. Tkatchenko, M. Scheffler, Phys. Rev. Lett. 2009, 102, 073005.

[22] a) R. Han, I. B. Gorrell, A. G. Looney, G. Parkin, J. Chem. Soc. Chem. Commun. 1991, 717-719; b) A. Looney, R. Han, I. B. Gorrell, M. Cornebise, K. Yoon, G. Parkin, A. R. Rheingold, Organometallics 1995, 14, 274-278; c) M. Rombach, H. Brombacher, H. Vahrenkamp, Eur. J. Inorg. Chem. 2002, 153-159.

[23] NIST Computational Chemistry Comparison and Benchmark Database, NIST Standard Reference Database Number 101, Release 16a, August 2013, Editor: Russell D. Johnson III, http:// cccbdb.nist.gov.

[24] Y.-S. Bae, R. Q. Snurr, Microporous Mesoporous Mater. 2010, $132,1121-1140$.

[25] B. Sakintuna, F. Lamari-Darkrim, M. Hirscher, Int. J. Hydrogen Energy 2007, 32, 1121-1140.

[26] A. Zaluska, L. Zaluski, J. O. Ström-Olsen, J. Alloys Compd. 1999, 289, 197-206

[27] D. J. Collins, H.-C. Zhou, J. Mater. Chem. 2007, 17, 3154-3160.

[28] P. D. C. Dietzel, B. Panella, M. Hirscher, R. Blom, H. Fjellvåg, Chem. Commun. 2006, 959-961.

[29] B. Liu, B. Smit, Langmuir 2009, 25, 5918-5926.

[30] a) E. D. Bloch, W. L. Queen, R. Krishna, J. M. Zadrozny, C. M. Brown, J. R. Long, Science 2012, 335, 1606-1610; b) S. J. Geier, J. A. Mason, E. D. Bloch, W. L. Queen, M. R. Hudson, C. M. Brown, J. R. Long, Chem. Sci. 2013, 4, 2054-2061. 